\title{
A cartography of dispossession: assessing spatial reorganization in state-led conservation in Saadani, Tanzania
}

\author{
Alejandra Orozco-Quintero ${ }^{1}$ \\ Leslie King \\ University of Victoria, Canada
}

\begin{abstract}
Proclaimed as the "most important conservation success story", protected areas have become the preferred method among state signatories to the Convention on Biological Diversity for addressing conservation challenges. However, state-governed protected areas have been criticized for their failure to achieve ecological and social goals. Reaching a consensus on wildlife conservation strategies has not translated into widespread acceptance of state-governed protected areas by local communities. Critics debate whether the state is sincere and efficient when exerting spatial control. This article analyses state-based conservation in the Saadani landscape in Tanzania, exploring the nature of spatial reorganization and institutional approaches guiding the establishment of protected areas. Spatial reorganization and the actions of conservation organizations have led to the disenfranchisement of the very people whose efforts had enabled biodiversity to be conserved. This is despite an apparent shift in the nature of Tanzania's conservation policies towards more participatory approaches. Through detailing mechanisms used by the state for exerting spatial control in Saadani, we highlight how the approach has been counterproductive for satisfying the country's commitment to the Aichi framework on biodiversity targets and has undermined grassroots backing for conservation. In the context of strong support from the international conservation organizations for Tanzania's conservation efforts, this suggests the need for reassessing global conservation policies and identifying urgent measures and effective mechanisms to protect rights to territory and ancestral tenure in places targeted for conservation.
\end{abstract}

Keywords: conservation, Convention on Biological Diversity, protected areas, spatial reorganization, actions of the state, Saadani, TANAPA, Tanzania. Uvinje

\section{Résumé}

Proclamée «la plus importante réussite en matière de conservation», les aires protégées sont devenues la méthode privilégiée par les pays signataires de la Convention sur la diversité biologique pour relever les défis de la conservation. Cependant, les aires protégées régies par l'État ont été critiquées pour leur incapacité à atteindre leurs objectifs écologiques et sociaux. L'atteinte d'un consensus sur les stratégies de conservation de la faune ne s'est pas traduite par une acceptation généralisée des aires protégées régies par l'État par les communautés locales. Les critiques débattent pour savoir si l'État est sincère et efficace lorsqu'il exerce un contrôle spatial. Cet article analyse la conservation étatique dans le paysage Saadani en Tanzanie, en explorant la nature de la réorganisation spatiale et les approches institutionnelles guidant la création d'aires protégées. La réorganisation spatiale et les actions des organisations de conservation ont conduit à la privation

\footnotetext{
${ }^{1}$ Dr. Alejandra Orozco-Quintero, P.O. Box 15605-00509 Langata-Nairobi, Kenya. Email: Aleja "at" uvic.ca. Prof. Leslie King, Canadian Centre for Environmental Education and School of Environment and Sustainability, Royal Roads University, Victoria, BC V9B 5Y2, Canada. Email: leslie.king "at" royalroads.ca. Our special thanks go to the leaders and decision-making bodies in the villages adjacent to Saadani National Park, particularly the leaders of Saadani village, who generously shared their time, knowledge and resources. Our sincere gratitude to park, district and other authorities for the time and information they shared. To research assistant Ally Abdalah, and to Madam Chanzu our heartfelt thanks, your accompaniment throughout fieldwork was essential to the successful conclusion of this project. Financial support for this research project came from a doctoral scholarship from the International Development Research Centre (IDRC) and the Social Sciences and Humanities Research Council of Canada (SSHRC) through the Protected Areas and Poverty Reduction Canada-Africa Research and Learning Alliance Project. We would also like to thank Dr. Lance W. Robinson for his valuable comments to the earlier version of this article and Dr. Rosaline Canessa for her constant support and supervision.
} 
des droits des personnes dont les efforts avaient permis la conservation de la biodiversité. Ceci en dépit d'un changement apparent dans la nature des politiques de conservation de la Tanzanie vers des approches plus participatives. En détaillant les mécanismes utilisés par l'État pour exercer un contrôle spatial à Saadani, nous soulignons comment l'approche a été contre-productive pour satisfaire l'engagement du pays envers le cadre d'Aichi sur les objectifs de biodiversité et a sapé le soutien de la base pour la conservation. Dans le contexte d'un soutien important des organisations internationales de conservation pour les efforts de conservation de la Tanzanie, cela suggère la nécessité de réévaluer les politiques mondiales de conservation et d'identifier des mesures urgentes et des mécanismes efficaces pour protéger les droits territoriaux et ancestraux.

Mots-clés: conservation, Convention sur la diversité biologique, aires protégées, réorganisation spatiale, actions de l'Etat, Saadani, TANAPA, Tanzanie. Uvinje

\section{Resumen}

Proclamadas como el "éxito más importante en conservación", la creación de áreas protegidas se ha convertido en el método preferido de los estados miembros del Convenio sobre la Diversidad Biológica para enfrentar retos de conservación. Sin embargo, áreas protegidas gobernadas por los agencias del estado han sido criticadas por su limitado éxito en alcanzar metas sociales y ecológicas, y el consenso en promover estas estrategias de conservación no se ha traducido en una aceptación generalizada por parte de las comunidades. Los intereses de gobiernos nacionales en, y sus habilidades para, ejercer control territorial para varios propósitos, incluyendo conservación, está bajo debate. Para lograr sostenibilidad ambiental y para sostener comunidades saludables se requiere comprender como la extensión de control de territorios opera como la pieza maestra en estrategias de conservación. Este artículo analiza conservación estatal en Saadani, Tanzania, para explorar la naturaleza de procesos de reorganización espacial y los métodos institucionales guiando el establecimiento de áreas protegidas. La reorganización de territorios y las acciones de organizaciones de conservación han llevado a la desposesión de la gente cuyos esfuerzos permitieron que la biodiversidad se conservara en el área de Saadani, a pesar de los cambios en discursos y políticas de conservación en Tanzania hacia la planeación participativa. Detallando los mecanismos usados por el estado para ejercer control territorial en Saadani, resaltamos cómo estos métodos han sido contraproducentes para satisfacer el compromiso del estado con las Metas de Aichi para la Diversidad Biológica y han socavado el apoyo comunitario a esfuerzos estatales de conservación. En el contexto del apoyo inequívoco del sector internacional de conservación a los esfuerzos de Tanzania, los hallazgos sobre Saadani sugieren la necesidad de reevaluar las premisas guiando políticas globales de conservación y de identificar medidas urgentes y mecanismos efectivos para proteger derechos comunales a la tierra y la tenencia ancestral en lugares seleccionados como objetivos de conservación.

Palabras clave: conservación, Convención sobre la Diversidad Biológica, áreas protegidas, reorganización espacial, estatal, Saadani, TANAPA, Tanzania, Uvinje

\section{Introduction}

A century after its creation, the Yellowstone National Park model, also known as "fortress conservation", has become one of the main strategies for the preservation of nature around the world (Brockington 2002). Officially recognized protected areas (PAs), which amounted to less than seven thousand in number in 1991, increased to 209,000 by 2014 (Juffe-Bignoli et al. 2014). Yet, in an alarming statement, the international conservation establishment acknowledged by 2010 that despite the steady increase in the number and extent of PAs, the goal set by world governments in 2002 "to achieve by 2010 a significant reduction of the current rate of biodiversity loss at the global, regional and national level as a contribution to poverty alleviation and to the benefit of all life on earth" had not been met (Secretariat of the Convention on Biological Diversity 2010: 9).

In response to this, in 2010, 192 state parties to the Convention on Biological Diversity (CBD) renewed their environmental commitments, by agreeing to make further efforts to halt the rate of biodiversity loss worldwide (Juffe-Bignoli et al. 2014). The commitments enshrined in the Aichi Biodiversity Targets agreed by the Conference of the Parties in Nagoya in 2010, include reserving $17 \%$ of world's terrestrial and inland water bodies and $10 \%$ of coastal and marine areas under conservation by 2020 (Convention on 
Biological Diversity 2010). By 2014 the UNEP's Protected planet report identified 15.4\% of the earth's land surface as PAs (Juffe-Bignoli et al. 2014). The internationally adopted system of targets for the expansion of PAs includes a diverse range of management objectives (from strict exclusion to sustainable use) and governance types (governance by government, indigenous peoples, the private sector, and mixed partnerships) (IUCN 2009). But as of 2014 of all the PAs reported on in the World Database of Protected Areas (WDPA), the vast majority conformed to the conventional model. UNEP's report indicated that $88 \%$ are being managed by governments while only $1 \%$ are managed by indigenous and local communities (Juffe-Bignoli et al. 2014), and of the $64 \%$ of PAs with stated management objectives at least $50 \%$ of those were under the most restrictive categories. Of these strict conservation PAs, 26.6\% are classified as national parks (Juffe-Bignoli et al. 2014).

Although statistics on the number of PAs under each IUCN category suggests that national parks are in the minority, they cover a significantly larger territory than other forms and so they are the dominant approach to conserving biodiversity (Chape et al. 2008). Because contemporary conservation practice still relies so heavily on this model, there is a need to further understand its strengths and weaknesses and, accordingly, take steps to improve or replace it.

While biodiversity loss is the product of a significant number of factors, including climate change, industrial and large scale agricultural development, and unsustainable use and overexploitation of resources, both the 2010 CBD report and the 2014 UNEP publication confirm the centrality of PAs. There is strong evidence that exclusionary conservation has major impacts on communities closely connected to and often fully dependent on biodiverse landscapes. These include Chase's (1987) thorough analysis of the negative impacts from top-down conservation policies and spatially disconnected conservation actors on Yellowstone's wildlife, as well as critical reviews on the lack of institutional fit and the harmful outcomes of applying the fortress conservation model in landscapes characterized by interdependent interactions between people and nature (Brockington et al. 2008; Chapin 2004; Dowie 2011; West and Brechin 1991; West et al. 2006).

In the context of widespread state support and significant commitments to global conservation accords calling for the expansion and multiplication of PAs (Juffe-Bignoli et al. 2014; Venter et al. 2014), there are important questions requiring further and urgent attention. Are current spatial and institutional conflicts in state-led conservation efforts mainly related to disagreement between strict and more inclusive paradigms for managing nature, or are they indicative of something else? In what ways can nominally "participatory" stateled spatial reorganization affect the effectiveness of conservation efforts and/or the social sustainability of PAs? In countries friendly to conservation, such as Tanzania, where one-third of the national territory is classified under PAs (IUCN and UNEP 2013), and conservation has been favored and systematically promoted by state agencies since colonial times (Goldstein 2004), top-down approaches have engendered conflicts between local communities and state agencies, and they have failed to channel conservation benefits to communities affected by or connected to national parks (Brockington et al. 2006; Goldman 2003; Neumann 1998).

In this regard, the article's central query is to explore the mechanisms through which PAs are being established and the effects of the conservation approaches taken. It adds to the sheer volume of accumulated evidence on the lack of fit between top-down conservation systems and community-based approaches to addressing biodiversity conservation. However, its main purpose is, rather than documenting the impacts of state-based fortress conservation, to illustrate some of the methods and stratagems used by the state for exerting spatial control. It elaborates on subtle, and often ignored, patterns of spatial reorganization and institutional practices, implicitly sanctioned by the international conservation establishment, which directly shape how conservation interventions take place, and the ways in which such practices undermine the roles played by various actors in biodiversity conservation and are counterproductive for achieving the central goals of global conservation frameworks.

\section{Governance and spatiality in conservation affairs}

Biologically diverse and culturally rich landscapes are inherently heterogeneous, and harbor a diversity of interactions between human and natural communities (Zimmerer and Young 1998). Conceptions of place, 
which shape and are shaped by these complex culture-nature interactions, have been translated into complex spatial and institutional arrangements where livelihoods, habitation and conservation are intrinsically linked through permeable boundaries and overlapping spaces (Berkes, Folke and Colding 1998; Roth 2008), and multi-use patterns and reciprocal co-existence (Colchester 1994). Today, a large body of empirical research, including research on the commons, community-based conservation, and community resilience provides a rich set of examples showing conceptions of space, the creation of place and the complexity of grassroots approaches to relating to and managing nature. This heterogeneity has been perceived and represented differently by conservation actors at different levels of social organization (Roth 2008; Zimmerman 1995).

The perception of biodiversity and the approaches adopted to protect it are mediated by cultural and political processes as well as by spatial relationships. Essentially political in nature, approaches to conservation translate into definite institutional and spatial relationships and outcomes. Institutions are critical components of governance systems that comprise the sets of binding rules, rights and normative procedures that frame collective decisions and actions, determining the mix of actors and steering their interactions (Young 1999). Institutions at every level of social organization are in constant tension and interact with other institutions at higher and lower levels (Underdal 2008).

Critically, customary and local level tenure and other institutions have been and continue to be directly and definitively disrupted by state conservation organizations and institutions. In strict forms of conservation, characterized by state control, the spatiality of PAs becomes an instrument to reduce human disturbance to a minimum through the removal of human communities, as this is thought to achieve better results in protecting biodiversity. However, this approach to conservation has been called into question because of the impacts it has had on communities whose lands have long fostered cultural and biological biodiversity, and on the very wildlife that PAs are intended to protect (Benjaminsen et al. 2013; Benjaminsen and Bryceson 2012; Brechin, Murray et al. 2007; Brockington 1999; Chapin 2004; Dowie 2011). Indeed, conservation success has not always been the norm across protected landscapes (Craigie et al. 2010; Mora and Sale 2011; Packer et al. 2011).

Disparities in conservation success can be attributed to multiple factors, including climatic, ecological and socio-economic circumstances (Venter et al. 2014; Watson et al. 2014; Wilson 2002). However, accumulated research suggests that a principal obstacle in conservation success is the approach to conservation itself (Barrett et al. 2001; Brandon et al. 1998), as well as the ways in which conservation practice is reminiscent of market practices (Igoe and Brockington 2007; Peterson and Isenhour 2014). These are trends which have been documented through analysis of policy and of management in Tanzania (Brockington et al. 2006; Benjaminsen and Bryceson 2012; Benjaminsen et al. 2013; Neumann 1998), and worldwide (Chapin 2004; Dowie 2011). In particular, state-controlled conservation developments spanning over a century have been subject to strong criticism for their persistent challenges to advance collective social and ecological goals (Aubertin and Rodary 2011; Benjaminsen and Bryceson 2012; Brandon et al.1998; Barrett et al. 2001; Brockington et al. 2008; 2011; West and Brechin 1991). Yet, state-managed PA systems remain the hallmark of current conservation efforts (Juffe-Bignoli et al. 2014), and are the most widely spread and significantly financed conservation format (James et al. 1999; Waldron et al. 2013).

The current global framework guiding the actions of states to address biodiversity conservation includes not only the well-known spatial targets for establishment of PAs, but also the more strategic level Aichi Biodiversity Targets. In the tenth meeting of the Conference of the Parties to the Convention on Biological Diversity, held in 2010, a revised strategic plan was adopted, and central to this was the 2011-2020 Aichi targets. They are the current measures that government parties agreed to translate into improved national strategies and action plans. Aichi's five biodiversity targets are:

a) addressing the underlying causes of biodiversity loss through mainstreaming biodiversity across government and society;

b) reducing direct pressures on biodiversity and promoting sustainable use;

c) improving the status of biodiversity by safeguarding ecosystems, species and genetic diversity; 
d) enhancing the benefits to all from biodiversity and ecosystems services and;

e) enhancing implementation through participatory planning, knowledge management and capacity building.

To what extent these five strategic goals have been pursued and have influenced the actions of states is yet to be documented. The spatial PA targets (17\% terrestrial and 10\% coastal and marine areas protected), despite their prominence, are merely one of several within these five goals.

So far, accumulated research on PAs has highlighted critical challenges at the level of planning and management, and a need for appreciation of the subtle aspects of the nature and impact of spatial reorganizations in conservation approaches. Aside from questions around planning and managementquestions around what to do-these challenges also compel an exploration of governance-questions related to the who and how of decision-making, including critical analysis of the frameworks guiding design and implementation (Robinson and Makupa 2015; World Resources Institute et al. 2003).

Over the past three decades, there has been some movement towards more inclusive and participatory state-managed PAs (Borrini-Feyerabend et al. 2004; Brechin, Wilshusen et al. 2003). There are also important advances in understanding the ways in which perceptions and organization of space can generate conflicts and opportunities among community and park actors (Roth 2008). However, despite progress in understanding the impacts of top-down conservation planning (Rantala and Vihemäki 2011), of removing peoples from their ancestral territories in the name of conservation (Brockington and Igoe 2006; Dowie 2011) and in recognizing the differences between people-powered and exclusionary conservation (Alcorn 1993; Borrini-Feyerabend et al. 2004; Colchester 1994; Stevens 1997), research has yet to thoroughly investigate the spatial reorganization dimension of state-based conservation and the establishment of PAs, ostensibly effected through participatory processes. This article draws on empirical findings on procedures and actions used by the Tanzanian state in the creation of Saadani National Park and on the spatial reorganization that this entailed. It documents how the state decided on, demarcated, and planned PAs at Saadani-first a game reserve and later a national park - and how this resulted in undermining of peoples' livelihoods and basic human rights. We argue that state-led conservation based on the conventional model of strict spatial control, rather than contributing to conservation, can, over time, profoundly undermine it and hinder achieving global goals to protect biological biodiversity.

\section{Case study background}

Saadani National Park (SNP), was established in 2005, and is especially significant among Tanzania's PAs because of its biological, ecological and cultural features, and its exotic location along the Indian Ocean coast. It is also the first park in the country comprising both marine and terrestrial zones (as shown in Figure 1). It is located within the Districts of Pangani and Handeni (Tanga Region) and Bagamoyo (Pwani Region). The park is surrounded by seventeen villages that are officially recognized and that have functioning village governments. These include the thirteen villages where research was carried out: Saadani, Buyuni, Mkwaja, Mikocheni, Mkange, Kwakibuyu, Gendagenda, Mbulizaga, Mkalamo, Kwansisi, Mkange, Gongo and Matipwili. Villages adjacent to SNP have ancestral connections to place through which cultural practice, habitation and livelihood processes have been shaped.

\section{Tanzania National Parks Authority policy on park planning and management}

TANAPA's early experimental efforts in community outreach date back to 1988, and have evolved into its national outreach policy and strategic action framework: Community Conservation Services (CCS) (Tanzania National Parks Authority 2005). CCS became an official organizational structure within TANAPA in 1992, and is currently a full-fledged department with permanent employees operating in every national park. TANAPA's Community Conservation Services Strategic Action Plan: 2005-2015 aims to increase linkages and collaboration with communities and various other stakeholders, in order to address TANAPA's overarching interests and goals.

However, as drafted, collaborative planning is only mentioned once in the entire policy document, as one of TANAPA's "core values." In addition, TANAPA's efforts in collaborative management activities are 
directed to support planning within fringe communities along park borders, not inside it. As stated, the salient goals of the plan are achieving between 50\% and $80 \%$ engagement of communities adjacent to parks in mutually beneficial conservation and resource management activities, including $25 \%$ of these communities operating functional land use plans (LUPs). In addition, the policy includes provisions to support communitybased projects, training and building capacity of staff and community-based conservation organizations, promoting local institutional development and interactions, and curbing poaching and park-people conflicts.

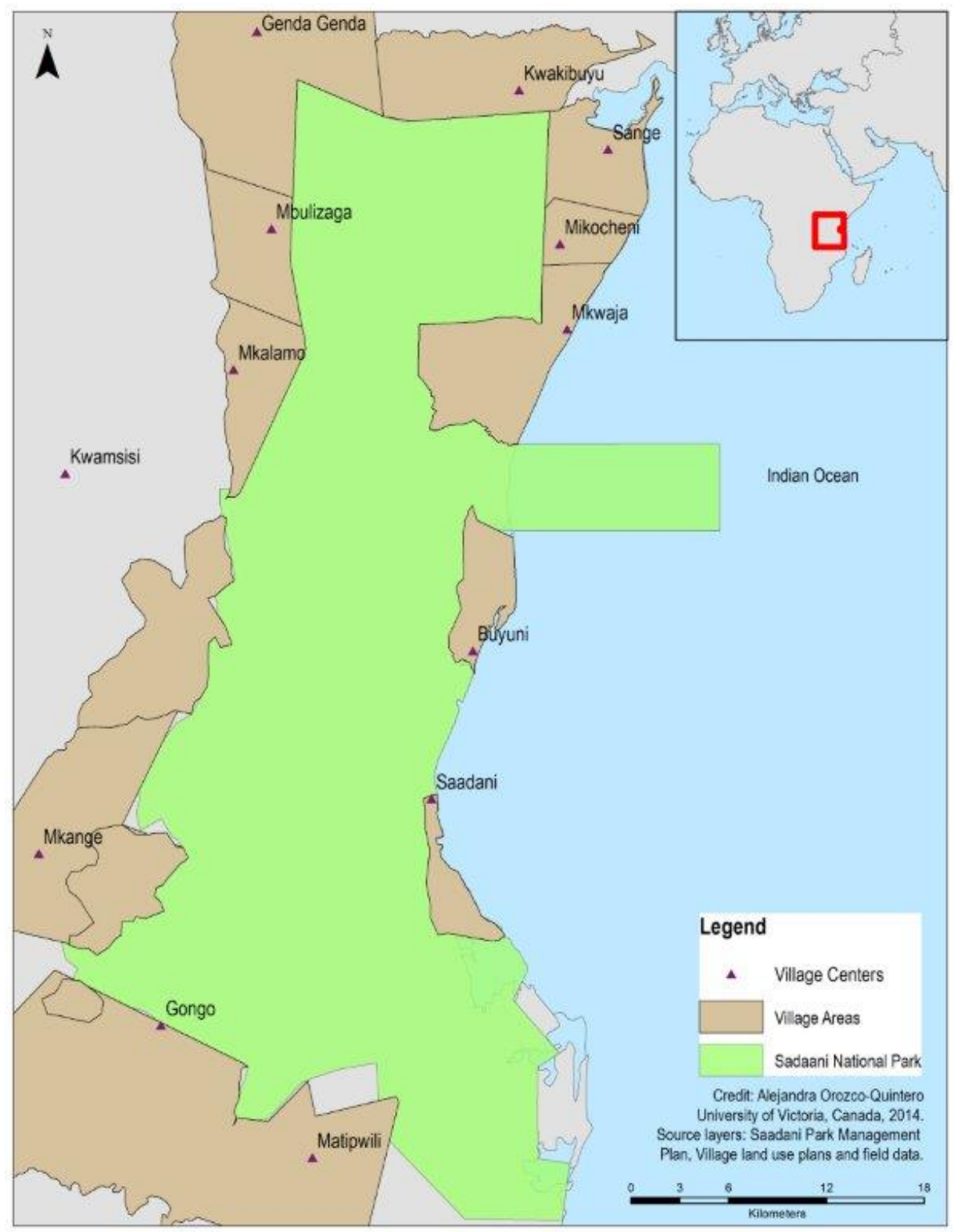

Figure 1: Map of Saadani National Park and adjacent villages that were involved in the research. Source layers: Saadani Park Management Plan, village land-use plans and primary spatial data. 
These policy provisions are intended to be connected to and supported by various other initiatives, including: training at multiple levels; harmonisation between park resource use and conservation laws and local and higher level legislative frameworks; research-based programming; and the promotion of alternative sources of income and other important park-initiated processes (Tanzania National Parks Authority 2005).

Based on TANAPA's guidelines, Saadani National Park's (SNP) own policy in collaborative park planning and management includes four programs of actions (Tanzania National Parks Authority 2009):

1) the Ecosystem Management Program;

2) the Tourism Management Program;

3) the Community Outreach Program, and

4) the Park Operations Program.

As described in the plan, the Community Outreach Program has been designed to bring about community "support and collaboration" to preserve "integrity of SNP resource values" through increased conservation education and park-community communication and cooperation (Tanzania National Parks Authority 2009: 5).

\section{Research methodology and data}

A larger research project took place over 18 months from 2012 to 2014 in the thirteen villages (Figure 1), talking to community leaders and village governments, and also park managers and government authorities in marine, land and resource planning at district and regional levels. Semi structured interviews took place with 217 individuals and in focus groups. This article is based around the qualitative, documentary and spatial findings pertaining to conservation interactions and outcomes taking place between Saadani Village and SNP. In addition, documents were gathered from various government, community and independent sources (both published and unpublished), dealing with the creation of the park, management zones, village land use and resource planning, and other secondary data.

Research participants included elected village leaders, elders in institutional bodies and local government staff. Key informants included district and regional level authorities and government personnel from Tanga, Dar es Salaam, Handeni, Pangani and Bagamoyo Districts. Individual interviews involved park wardens for resource protection, community outreach, and ecology, and park administrative staff. The qualitative and document analyses were done using NVivo software. The gathering of spatial data involved taking GPS points and transects of PA boundary beacons, community boundaries and conserved areas, village centers and other relevant sites, and areas with overlapping park-community claims. Forest walks and other field visits to collect primary spatial data were made with community leaders and key informants. In its totality, the spatial data included primary GPS points and transects and secondary data on village land use plans, landscape-level conservation efforts, park boundaries, community reserves and related data on village settlements and places of interest. Spatial data analysis involved using ArcGIS for digitizing paper-based maps, tracking and geo-referencing vector data (points, transects and polygons), developing maps and doing visual cartographic analysis. This involved tracing original boundaries using GPS-collected data and digitized paper maps, doing map overlays and developing new polygons to show areas of concern and boundary mismatches, to illustrate the coupled nature of spatial and institutional processes in the Saadani landscape.

\section{Findings}

\section{Landscape interventions preceding Saadani National Park}

The creation of SNP was only one of several interventions in the Saadani landscape. Saadani's oldest and most important development intervention dates back to the 1950s when the Mkwaja Ranch was established (Pangani District Archives). Figure 2, found in archives from Pangani District, shows the original map of the ranch. As can be seen later in Figure 6, the former Mkwaja Ranch comprises most of the northern 
portion of the current SNP. Leaders in the thirteen villages adjacent to SNP consider Mkworozaja Ranch to have had important impacts on their socio-economic development during its four decades of existence.

Saadani's other two significant conservation interventions were the creation of Saadani Game Reserve (SGR), which was officially established in 1974 (but operating since 1968) (Department of Wildlife and The Republic of Tanzania 1968) and Zaraninge Forest Reserve, proposed in the 1990s and officially established in 2000 (Tanzania National Parks Authority 2003). The level of awareness among Saadani villages of environmental conservation led to and was enhanced by the establishment of Saadani Game Reserve (Mwinyamane 1994, 2003). Primary and archival research shows that SGR was an outcome of a concerted institutional effort between community leaders and elders and the Department of Wildlife to enable conservation and community habitation on the same landscape.

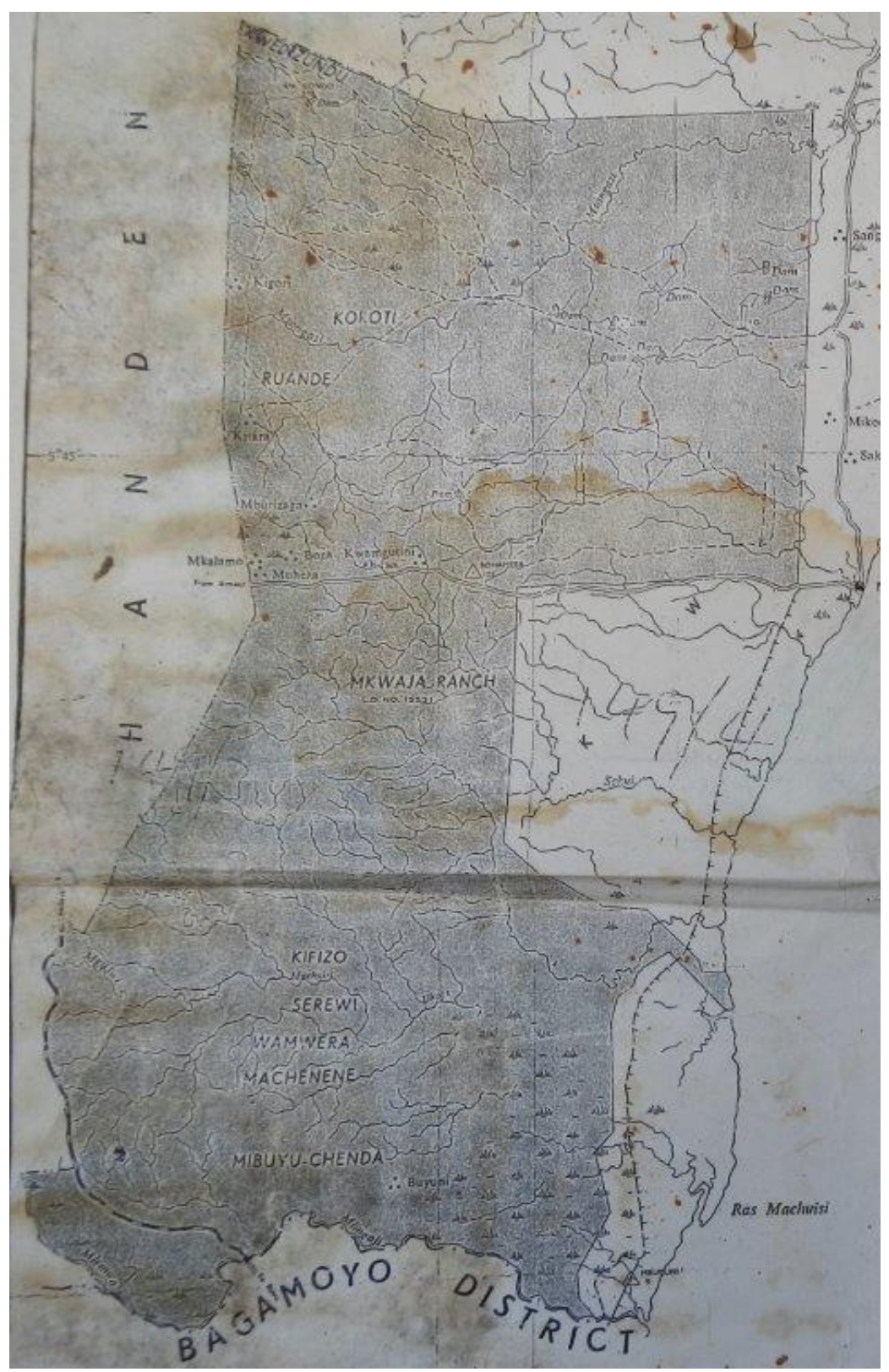

Figure 2: Historic original map of the former Mkwaja Ranch. (Source: Pangani District Archives) 
While engaged communal labour in the 1960s, villagers from Saadani noticed the presence of the then director of the Department of Wildlife, Mr. H.S. Mahinda, who was passing by the village on his way to Pangani District. Determined, the villagers requested Mr. Mahinda's support to stop the indiscriminate killing of wildlife by foreigners and people from the adjacent districts (Mwinyamane 1994, 2003). This interaction led to the establishment of what would become known as the community-initiated and supported Saadani Game Reserve (SGR) in the late 1960s (Mwinyamane 1994, 2003).

Documents describing the process of creating agreement and showing the exact location of the reserve boundaries are absent from the records held by Tanzania National Archives. However, other available records including numerous SGR annual reports - some hand-written and signed by Mr. Mahinda and dating back to 1968 - depict the Wildlife Division's policy for addressing conservation hand-in-hand with communities. These reports describe, among other things, efforts in community capacity development, village engagement in tourism management, and collective decision-making (Department of Wildlife and The Republic of Tanzania 1968). Data from interviews with elders, as well as SGR's historical reports and historical village documents suggest that SGR enabled multi-level partnerships, the building of trust, collective decisionmaking, collaborative wildlife management, and progress in ecological conservation, during its three decades of operation.

In terms of spatial arrangements, the SGR reports make it clear that there were no requests to have coastal village settlements vacated or relocated, but only two inland sub-villages, which were moved because their settlements were right at the heart of the proposed game reserve (one of them known as Tengwe) (Department of Wildlife and The Republic of Tanzania 1968). Figure 3, sourced from a 1997 technical report from the University of Dar Es Salaam (UDS), shows a map of all three interventions: Mkwaja Ranch, SGR and Zaraninge Forest Reserve. SGR is identified as No. 3, to the north is the area comprising Mkwaja Ranch, and Zaraninge Forest Reserve located west of SGR and identified as No. 4 on the map. Also included in the UDS report is a geographically referenced version of SGR (Figure 4). Both map versions of the SGR make it clear that little beach land was included in the reserve. The report also states that the reserve's beach is "not as expansive as perceived." In reality, only "up to $2.5 \mathrm{~km}$ " of beach "from Mvave river, located north of Saadani village centre, up to Kijitokombe river mouth, the south boundary of Uvinje sub-village", comprise the totality of the reserve's coastal stretch (University of Dar Es Salaam and Institute of Resource Assessment 1997: 3). The UDS report's contents are particularly important to verify spatial arrangements at the time of the reserve's origins, since the report was commissioned by the Department of Wildlife itself, and is in agreement with the Reserve's gazette. Equally important in understanding the agreement between the Wildlife Division and Saadani village is the original gazette of SGR (1974), presented in Figure 5. Although vague in the description of SGR boundaries, the gazette states that SGR's north east boundary was demarcated by a "cleared and beaconed line."

Conversely, since the establishment of SNP in 2005, park authorities have taken systematic steps to evict Saadani villagers inhabiting two of its three main coastal settlements, Uvinje and Porokanya. Village authorities have persistently argued, since before the official enactment of the Park, that their lands have never been part of the Reserve (The Independent Daily Newspaper 2003) and, afterwards, have consistently communicated that they will refuse to be removed from their ancestral lands (Mawio NewsPaper 2013). The process through which the park was established, and the spatial organization outcomes it precipitated, help to illustrate critical spatial and institutional aspects engendering park-community conflicts in a landscape formerly known for its successes in collaborative conservation.

\section{Decision-making in the establishment of Saadani National Park}

The achievements in collaborative conservation and the communities' perceived progress in biodiversity conservation at SGR would eventually play a dual role in the establishment of SNP. First, it called on the attention of Tanzania National Park Authority (TANAPA) to create, in the late 1990s, the country's first coastal national park, and enabled it to have a positive reception at the early stage of park planning. Interview data from the TANAPA official who had been in charge of establishing the park, Domician Njao, as well as 
TANAPA reports and park establishment documents, point directly to public participation in park planning, as the primary means of finding agreement with village representatives to establish the park (Bagamoyo District Board 2001, 2002; Tanzania National Parks Authority 2002, 2009).

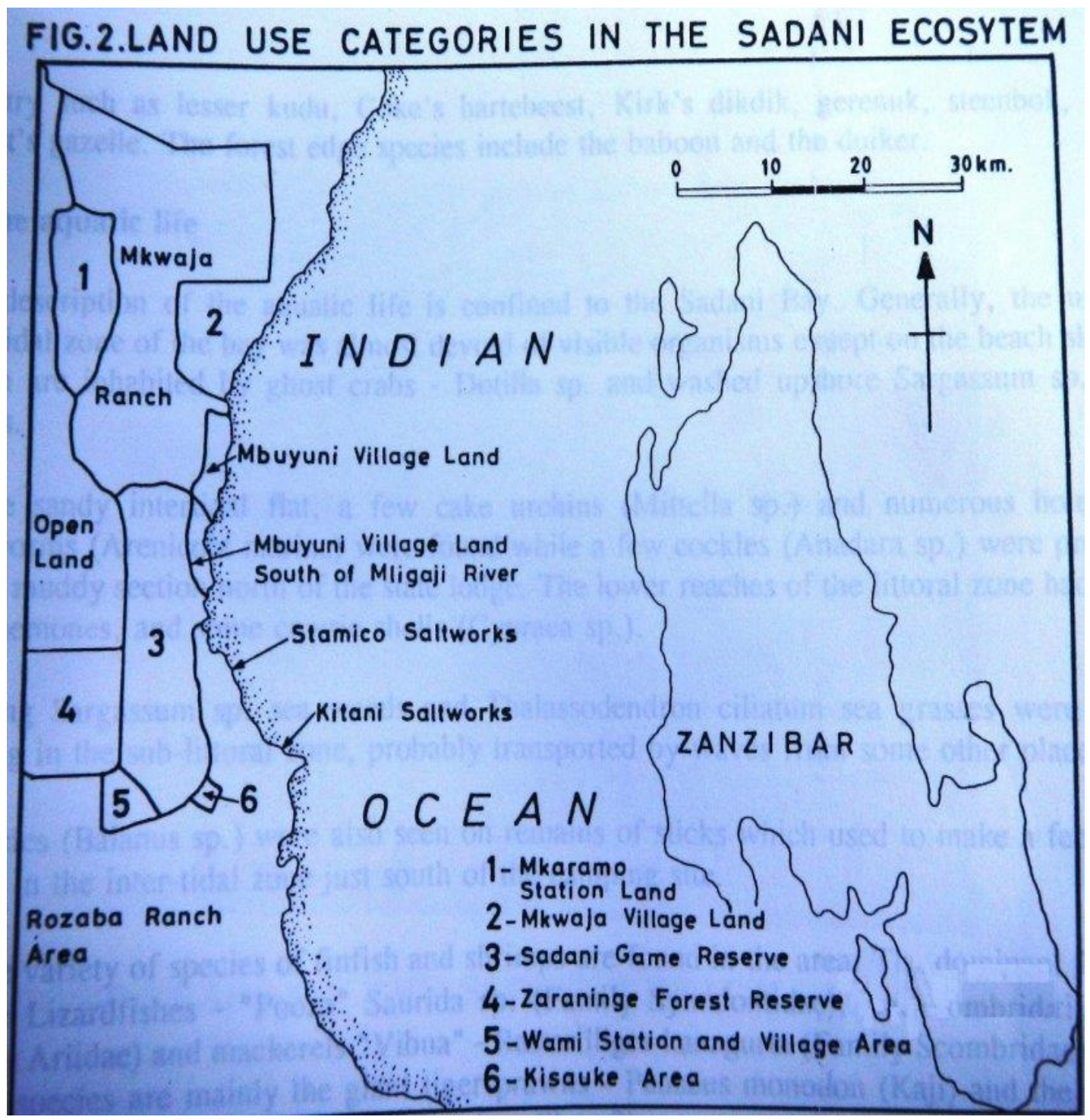

Figure 3: The oldest Map of Saadani Game Reserve found to date. (Source: 1997 Report on Research Commissioned by the Department of Wildlife to the University of Dar es Salaam. IRA Library: Ref No. TD 194.6.T34. E68). 


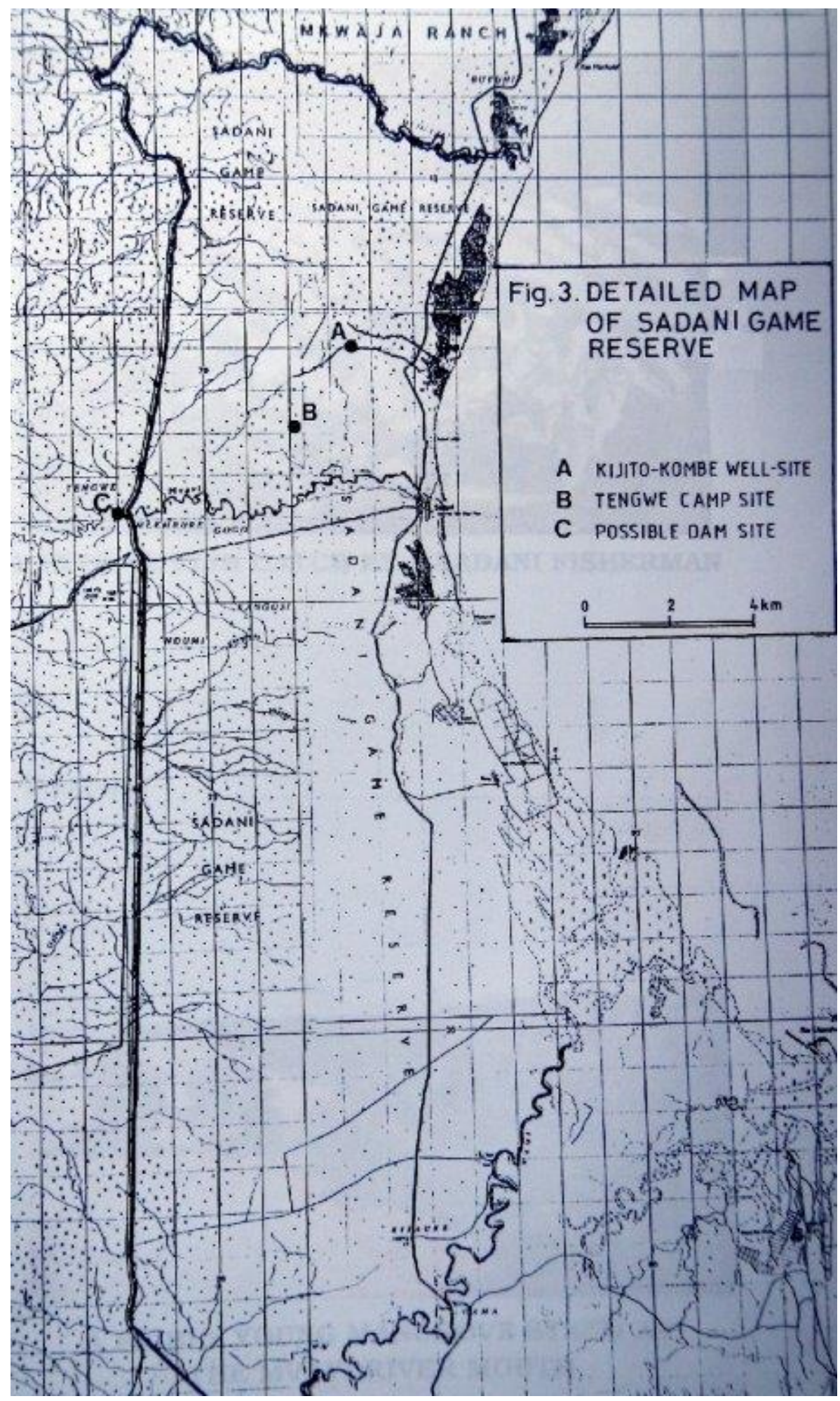

Figure 4: Geographically referenced version of SGR based on the oldest map of the reserve (Figure 3) also found in the 1997 report on research commissioned by the Department of Wildlife to the University of Dar es Salaam (Ref No. TD 194.6.T34. E68). 


\section{H'ildife Conservation (Gane Reserves)}

G.N. No. 275 (conid.)

Scrial

Name and Boundary Description

No.

12 SaAdant Game Ri:irve

Eouritarics:

"Commencing from the point where the Ruvu/Mnyusi railway line crosses the Milligaji River the boundary follow's the nurth side of the said ri.er Jownstream to the Indian Ocean; thence in a southerly direction along a cleared and beaconed line for approximately cight hilomotres to a beacon situated about half a kiloinctre north of Saadani Village: thence followine a cleared and beaconed line, lcaving Saadani village and Marumbi salt-works to the east, in a south-easterly direction to the point where the Wami River enters the sea; thence following the said river upstream for approximately two kilometre to a beacon on the north bank; thence in a northerly direction along a cleared and beaconed line for ahout two kilometres to a beacon nerth-east of the Kisauke Sisal Factory; thence in a westerly direction along a cleared and beaconed line, leaving the Kisauke Sisal Factory to the south, to a beacon on the Kisauke;Wami Station road; thence along a cleared and beaconed line, leaving Masuke Village to the south, to another beacon on the Kisaukc/ 'Wami Station road; thence following the said Icad in a generally westerly direction to a beacon where the rom swings south; thence west-wards to the Ruvu/Mnyusi railway line: thence f fllowing the said railway line due north to the point of commencencin."

Figure 5: Original gazette (1974) of the community-initiated Saadani Game Reserve. Source: Government Printing Office, Dar es Salaam. Online: https://www.tnrf.org/sw/node/5574

Throughout the TANAPA reports, public participation is said to have been a central mechanism used to establish the park (Tanzania National Parks Authority 2002, 2009). TANAPA hosted numerous workshops and multi-stakeholder meetings at district levels, where village representatives were invited to discuss the feasibility of establishing the park (Bagamoyo District Board 2002; Tanzania National Parks Authority 2002). These events have been documented by park and district sources, which describe the number of meetings and agenda items guiding meetings with district and the participating village authorities. However, none of the records reviewed in this research include concrete information on the park's geographic extent, location of boundaries, and the amount and location of village lands destined to become part of the proposed park. As described, meetings to seek approval from village leaders and decisions made were almost entirely based on TANAPA's input on the ecological importance of establishing the park, with the exception of one district 
level presentation of a TANAPA created map of SGR. In that meeting TANAPA's map of SGR was presented to Bagamoyo and other District Authorities, and at that meeting participants approved the creation of SNP (Tanzania National Parks Authority 2002).

Figure 6 is a map describing the former management and ownership and lands now comprising the full extent of SNP, land uses, former village territories and places of significance to adjacent villages. Prominent among the various land uses are communities' conserved, no-use and special management areas that surround and mostly pre-date the establishment of the park. Lands comprising the northern portion of the park are largely constituted by the full extent of Mkwaja Ranch, and to a lesser extent by former communities' fishing grounds and village lands. Similarly, the southern portion of the park is divided into two main categories: former village territories and lands previously owned or managed by district and national agencies. Lands under former government interventions include Zaraninge Forest Reserve (formerly managed by Bagamoyo District),a portion of Rezaba Ranch (formerly owned by the Government of Zanzibar). Figure 6 also shows TANAPA's map of the boundaries of SGR, which had been under the management of the Department of Wildlife. This map of SGR location and boundaries was the one employed to inform decision-making at the district level on establishing SNP (Tanzania National Parks Authority 2002).

\section{Cartographic analysis of Saadani Game Reserve and Saadani National Park}

Cartographic analysis was used to synthesize all available data on boundaries of SGR and the other territories that were brought together in SNP and to analyze the various conflicting versions of the boundaries that pertain to SGR and Saadani Village. This is presented in Figure 7, which shows on the left, TANAPA's maps of SGR and SNP and the former extent of villages' territories and, to the right, a zoomed view of the overlay of the two differently sourced map polygons on SGR, the one from TANAPA (which was created between 1999 and 2001, as shown in the left) and the one from the UDS report commissioned by the Department of Wildlife (dating back to 1996-1997, Figure 4, above). Added to this overlay are critical landmarks on Saadani's inhabited sub-village areas and the location of two of the original SGR boundary beacons that were discovered by villagers and the authors in the 2012-2014 period during which the field research took place. As can be seen, the overlay of the two different polygons on SGR reveals the extent of Saadani's inhabited lands gazetted as part of SNP and the amount of land left to Saadani village.

Neither the location of the beacons of the former reserve nor the map in the 1997 UDS report indicate that the Game Reserve's eastern boundary extended all the way to the sea. By definition then, the Department of Wildlife never included the inhabited coastal sub-village areas of Uvinje and Porokanya as part of the area comprising the original Saadani Game Reserve. The overlay makes it clear that TANAPA's map of SGR presents a completely different eastern boundary for the Reserve, a boundary that implies that the totality of Uvinje and Porokanya (Saadani's two main coastal sub-villages), as well as part of the Saadani Village centre were part of SGR. There is no record that during the game reserve period SGR was ever extended to annex those or any other lands. Nor could we find any data to suggest that district and other authorities were aware of the changes made to the original map of SGR when the map was presented by TANAPA at the district level in the process of getting approval for the park.

According to park establishment records, TANAPA has consistently argued that Uvinje and Porokanya areas have always been within the reserve (Tanzania National Parks Authority 2002, 2014a). TANAPA's new cartography of SGR was unambiguously supported during efforts by park authorities to modify the original agreement made with Saadani elders (contained in the excerpt from the SGR gazette, Figure 5) and to argue that such village lands have always been within the original SGR and now belonged to the park (Tanzania National Parks Authority 2014b).

The partial document view of TANAPA's interpretation of the original 1974 SGR gazette notice, shown in Figure 8, illustrates TANAPA's procedural methods to normalize a different description of the SGR 
boundaries. In the particular case of the lands that pertain to Uvinje sub-village, in the 1974 boundary description TANAPA added the clauses "to where the river enters the ocean" and "from the mouth of the Mligaji River...(along the coast)", and fully omitted "then in a southerly direction along a cleared and beaconed line..." (see the 4th line of the original 1974 SGR gazette, Figure 5 above). In the interpretation pertaining to Porokanya's lands, TANAPA just added the phrase 'at Porokanya' in the $9^{\text {th }}$ line of the original gazette where it says "to where the Wami River enters the sea (at Porokanya)". Significantly, topographic and rainfall conditions of the Saadani coast are such that during rainy periods estuarine areas (where rivers enter the ocean) can extend up to $3 \mathrm{~km}$ upstream. These conditions might explain why the official gazette seems to suggest that the Reserve's eastern boundary extends down to the mouth of Mligaji and/or Wami rivers. Nonetheless, in the 1974 SGR gazette (Figure 5) it is written that a "cleared beacon line" was built to demarcate the boundary at Uvinje and southwards. TANAPA's interpretation of the original SGR gazette has officially left Saadani village with approximately $12 \mathrm{~km}^{2}$ as the entire extent of their remaining village land, of which part is seasonally flooded and used for salt mining.

There are no official documents relating to the establishment of the Park which identify how Saadani village's land was being added to the park. Nor could we find any evidence that TANAPA explained that this was happening, for example during the formal presentation to Bagamoyo District. To the contrary, documents relating to Park establishment in the area near Saadani directly state that park authorities committed to return a $1.5 \mathrm{~km}$ buffer zone from SGR lands (around Saadani village centre) back to Saadani villagers (Bagamoyo District Board 2002; Tanzania National Parks Authority 2002). Yet the former SGR's eastern boundary did not shift west to fulfill this commitment, but instead was moved all the way to the coast to incorporate most of the close to $50 \mathrm{~km}^{2}$ of land that former village leaders had left for their habitation, leaving them with only 12 $\mathrm{km}^{2}$ as the full extent of their territory. The map of SGR used by TANAPA (see Figure 7) and its description of SGR boundaries (Figure 8) present the spatial reorganization and the procedural path taken by TANAPA to rescind the villagers' tenure rights. 


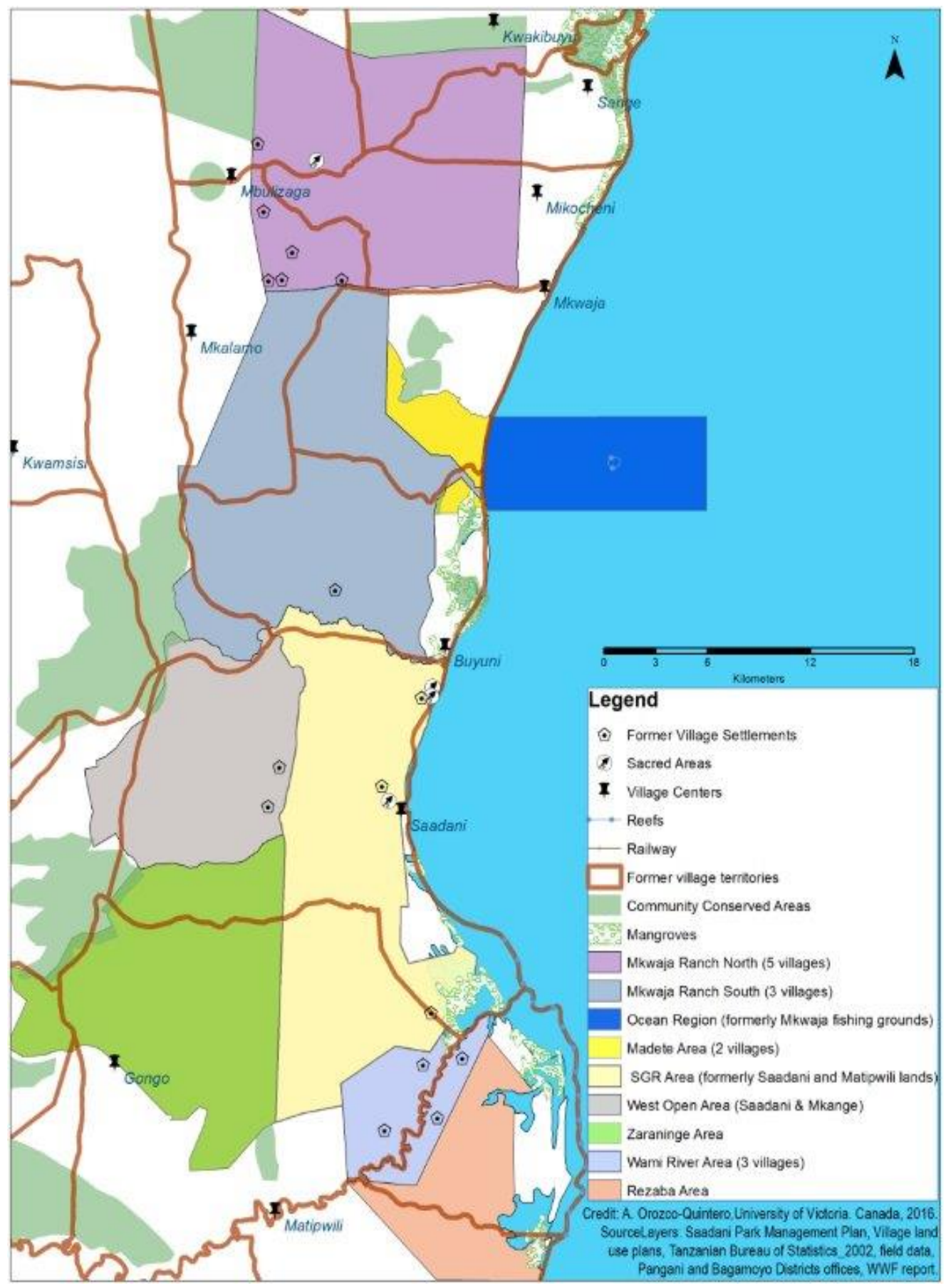

Figure 6: Former management and ownership of lands comprising SNP and significance of park lands and important land use designations around SNP. (Sources: Saadani 2010-2020 park management plan, Tanzania Bureau of Statistics 2002 Census, Technical Report and others listed) 


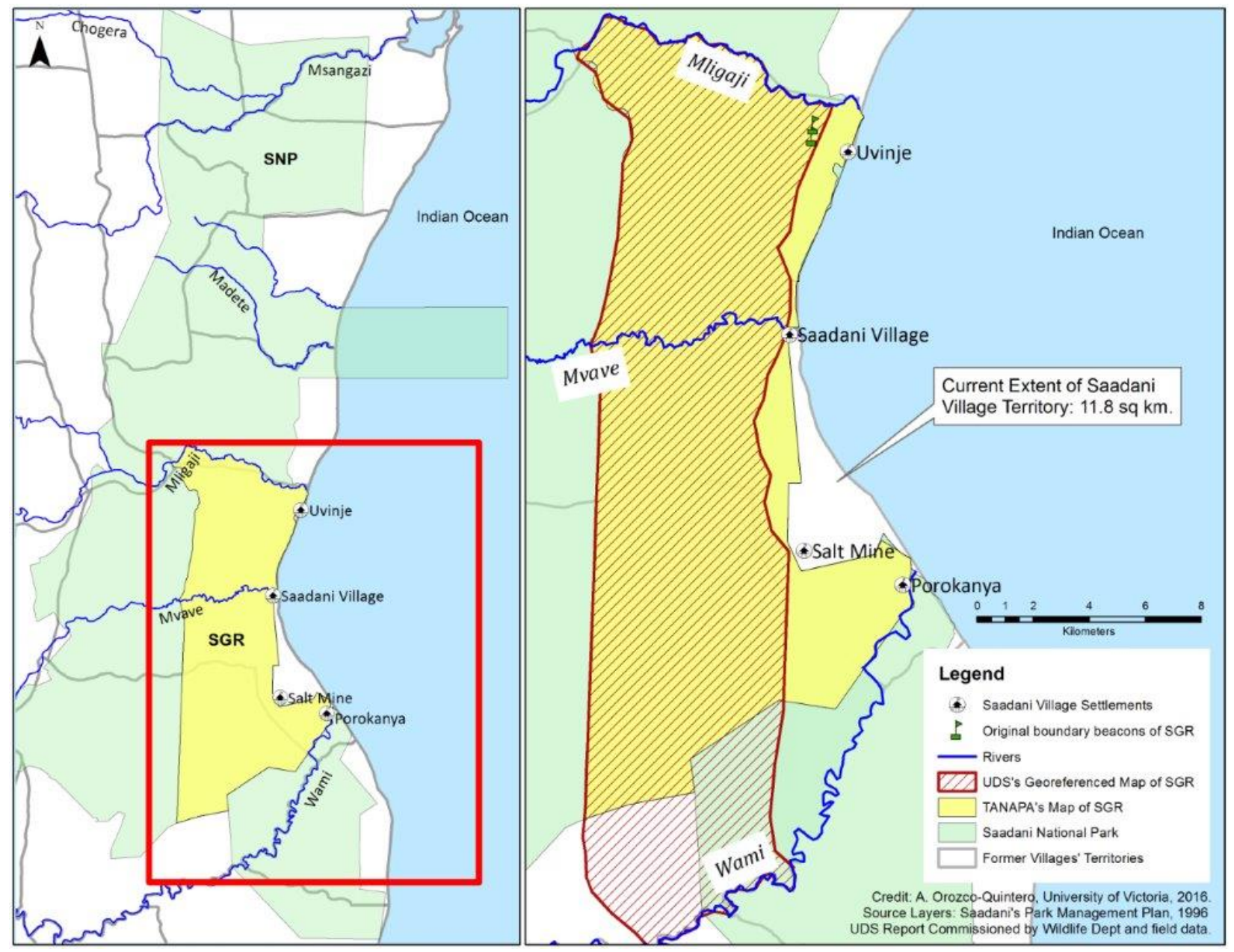

Figure 7: TANAPA's maps of SGR and SNP (left) and a zoomed view showing the overlay of the two differently sourced polygons on SGR (right). (Source layers: 2010-2020 Saadani Park Management Plan, 1997 UDS report, primary spatial data)

\section{A park of conflicts in a conservation-friendly social landscape}

Park planning approaches implemented since the late 1990s and identified as "participatory" have not prevented SNP, officially established in 2005, from being confronted since its inception with multiple conflicts, including boundary and land disputes along its borders. Addressing biodiversity conservation has been incrementally more difficult with park statistics describing a seven-fold increase in poaching activity since the establishment of the park. While in 2005 there were 32 reported offences, by 2011 the number of cases was 224 (Saadani National Park 2013). Conflicts over park lands and boundaries have arisen with both village and district authorities, and apply to the lands under former conservation interventions (SGR and Mkwaja Ranch) and to the newly acquired village lands (Bagamoyo District Commissioner 2005; Matipwili Village 2011). Yet, it is the particular case of Saadani Village, whose importance was acknowledged in the 
naming of both the reserve and the park, where spatial reorganization has had the most significant impact on grassroots engagement in environmental conservation and communal land tenure rights.

\section{Boundary Description for Saadani Game Reserve In accordance with the Wildife Act of 1974}

Commencing at the point where the Ruvu / Mnyusi railway line crosses the Mligaji River (Point A 467480;9432468), the boundary follows the northern bank of the Mligaji River to where the river enters the Indian Ocean (Point B: 477755; 9340089).

From the mouth of the Mligaji River, the boundary extends in a southerly direction (along the coast) for $8 \mathrm{~km}$ to a prominent Mvinje tree on the beach (Point C: 475691; 9332423). which is south of the reserve resthouse and current location of a tourist camp

From the Mvinje tree the boundary comes inland westwards for $0.5 \mathrm{~km}$ to the road at the point of the pumping station of the Saadanı Game Reserve (Point D: 475189, 9332373)

From the road at the pump station, the boundary extends southwards leaving Saadan! Village and Marumbi Saltworks to the East until reaching Point E $(475710,9326684)$

From Point $E$ at Marumbi, the boundary extends to where the Wami River enters the sea at Porokanya (Point F: 479605; 9324242).

The boundary then follows the Wami River upstream to Chamanyani (Point G. 479270 : 9322239), which is $2 \mathrm{~km}$ from where the river enters the sea.

From Chamanyani, the boundary follows a southwesterly direction for $4.1 \mathrm{~km}$ to Msakangato (Point H: 476920; 9318972) and then turns to takes a diversion around the old Kisauke sisal estate. This gives rise to three points I. J and K (Point I. 474954; 9319230). (Point J. 471860, 9317171) and (Point K 471915; 9316035) passing through Maguko and Mtoa Ngoma From Mtoa Ngoma the boundary extends westwards to Tengwe on the railway line (Point L: 467857: 9315303). From Tengwe the boundary follows the railway line in a northerly direction to the point of commencement (Point A).

\section{Page 6}

Figure 8: Partial document showing TANAPA's interpretation of the original 1974 SGR gazette notice - shown in Figure 5. Source: 2014 Letter from TANAPA (Ref No. LAG/SA/1) to the Lawyers' Environmental Action Team (LEAT)

Practically, former Saadani Village leaders first enabled the creation of SGR by giving close to $40 \%$ (of the approximately $300 \mathrm{~km}^{2}$ ) of their territory, and later agreed to give an additional $45 \%$ (about $128 \mathrm{~km}^{2}$ ) of their inland territory for the creation of SNP, effectively leaving to themselves approximately $15 \%$ of their original territory (close to $50 \mathrm{~km}^{2}$ of land). This grassroots contribution to the PA was encouraged by international agencies (Baldus, Roettcher and Broska 2001; Treydte 2004) and well-supported by international conservation and other organizations, including GTZ, WWF and Fondo Per la Terra (Bagamoyo District Board 2001). Saadani's total land contribution to state-led conservation comprised no less than $80 \%$ of the full extent of its village territory, and took place despite the fact that Saadani, together with adjacent 
villages, had their own community-conserved areas equivalent to at least $20 \%$ of the park's area. Nevertheless, as of 2017 Saadani villagers are legally entitled to only $11.8 \mathrm{~km}^{2}$ of the $50 \mathrm{~km}^{2}$ of village territory they retained for their habitation.

For what is now over a decade, people from Uvinje and Porokanya sub-villages have been portrayed as encroachers on their own ancestral lands and are being subject to regular eviction threats by park authorities (Mwinyamane 2003; Tanzania National Parks Authority 2014b; Uvinje Subvillage 2002, 2003). Group discussions and field walks with members of Saadani Village Council, the main village government body, most of whom are the second or third generation descendants of the villages' conservation pioneers, suggest that community leaders perceive park authorities as operating as a government of their own. We also found that there is lack of knowledge on the actual location of current park boundaries surrounding the village center, a limited understanding of boundary agreements at the time of SGR, and a lack of awareness - and therefore lack of informed agreement—on the legal scope of Uvinje's and Porokanya's as well as Saadani's own rescinded land rights.

For over a decade TANAPA rhetoric has portrayed the village's inhabitants along the coast as encroachers in the former SGR: "...the sub-village [Uvinje] is located in the reserve illegally. A mistake was done by letting people live there and the population grew by the day" (Tanzania National Parks Authority 2002: 4); "the sub-village [Uvinje] is located inside the park against the law. It was wrong to let residents live and increase in population in that area..." (Bagamoyo District Board 2002: 4); "Uvinje suburb has been inside the boundaries of SGR and the residents of this suburb have been staying within the reserve even when it was being upgraded to a national park...it is clear that the residents of Uvinje are inside the park and stay in that area illegally. The efforts to evict these people from the park are continuing" (Tanzania National Parks Authority 2014b: 2). The persistent repetition of this rhetoric has gradually eroded the willingness of some village leaders to defend their own communitys' rights and delayed the chances of finding a timely resolution to a land dispute about which there is concrete empirical evidence showing the original boundaries of SGR.

Members of Uvinje, who enabled and participated in conservation management at various levels as office staff and as field guards, have consistently indicated their support to conservation through their collective disapproval of poaching and have gone beyond discourse alone with their autonomous decision to stop salt-mining. This was because of its detrimental impacts on conservation, even though it was their main source of income (Mwinyamane 2003). However, TANAPA tried to lend these lands to international investors for the construction of a luxury tented camp (Tanzania National Parks Authority 2011). This call to investors was undertaken despite the fact that villagers in Uvinje have been systematically prevented from finishing an eco-lodge, started soon after the establishment of the park in 2006. They were its shareholders and would have been its main managers (The Republic of Tanzania and Ministry of Rights and Human Settlements Development 2009).

International advocacy efforts were exerted through six letters of appeal to the former and current Presidents of Tanzania, by

a) the Global Consortium of Indigenous and Local Communities' Conserved Territories and Areas,

b) letters to the African Union and the United Nations Special Rapporteur on the Rights of Indigenous Peoples by Minority Rights Group International

c) ongoing legal support from international organizations.

These called for the reinstatement of Saadani villagers' land rights and their inclusion in biodiversity conservation. The improprieties that have taken place have been highlighted by at least three other independent research reports (Commission on Human Rights and Good Governance 2017; Legal and Human Rights Centre 2017; Ngorisa, Tenende and Msuya 2014). One of them conducted by Tanzania's own ombudsman concluded that TANAPA's actions to establish SNP "went contrary to the requirements of the law" (Commission on Human Rights and Good Governance 2017: 1). All of these efforts have so far been of little help in achieving redress, which requires political will. 


\section{Discussion}

Various interventions by different state actors over the years in the Saadani landscape have had direct consequences for institutions and spatial organization; however, the findings suggest that it was the establishment of SNP which has had the most striking consequences for conservation efforts. The area, rich in biodiversity, has had a history of community stewardship. The creation of SNP, however, marked a turning point. The findings on the nature of community engagement, or lack thereof, in the redrawing of boundaries and reinterpretation of previous agreements, together with the lack of essential information during park planning consultations and decision-making, show there are radical differences between the state's discourse on community involvement in conservation and actual participatory conservation planning that would enable communities to play their role in protecting biodiversity. Villagers and district level agencies had only limited access to information and, as described above, crucial aspects of that information on park boundaries were inaccurate. The only superficial engagement of village leaders during park creation enabled TANAPA to unilaterally reinterpret former community-agency agreements and to modify collectively agreed upon spatial boundaries.

The effects of TANAPA's actions have been multifaceted. Saadani villagers had proven their genuine interest in biodiversity conservation, as shown by the fact that not only did they invite the Department of Wildlife to help them, but they actually made it a reality by entrusting a large portion of their traditional lands for the creation of SGR. TANAPA's actions have disrupted the steps these communities had taken to preserve their biodiverse landscape, and made them officially landless and unable to sustain themselves in the process. Recent statistics on poaching activity and growing social discontent suggest that that the creation of SNP has not only had negative social consequences, but it has also undermined conservation successes achieved during preceding decades.

TANAPA's systematic efforts to gain full control of not only biodiversity-rich, but also culturally important and touristically valuable areas, had the support of international conservation organizations. This also illustrates the spatial and institutional mechanisms through which state-based PA governance and management can impair or erode chances of making conservation a multi-level effort equally embraced by national and international organizations, and by the communities whose lands have become the target of conservation. The role of Saadani villagers and their actions to establish an eco-lodge to pursue environmentally-friendly development makes it difficult to justify appropriating their ancestrally inhabited lands, as these villagers had shown that they pose no threat but rather are an ally in conservation efforts. Yet what might be most suggestive of a profit-driven, rather than conservation-driven, agenda is the Authority's call to international tourism investors to lease the land, a call that would enable the agency to multiply its profits, and that took place despite the community's engagement since 2006 in ecotourism, operating with the approval of another arm of government.

Although there are clear differences between current strict stale-led PA models, which separate humans from nature, and indigenous approaches, in which humans are understood as part of nature, these differences are not what is driving conflict in the Saadani landscape. Certainly, there are differences between the villagers' stewardship of nature and the state's approach to conservation, but what is driving conflict is the state's questionable approach to spatial control through seemly participatory environmental governance. As the findings illustrate, TANAPA's conservation planning and management has not only led to the unfair dispossession of a community that cares about conservation, but it is counterproductive to the achievement of the Aichi Biodiversity Targets A, D and E: addressing the actual causes of biodiversity loss, ensuring benefits to all those connected to conservation and conserving through participatory planning.

A large volume of research illustrates how numerous and vast biologically diverse areas, once under the management of grassroots actors, have been stripped of cultural diversity and are now controlled by national and international actors. Locally, this is part of the push to increase the extent and coverage of PA in Tanzania (Brockington and Igoe 2006; Benjaminsen and Bryceson 2012) but also worldwide (Brockington and Igoe 2006; Dowie 2011; Juffe-Bignoli et al. 2014). As it stands, spatial reorganization and overlapping land and resource use and management processes emerging from, or connected to, the establishment of PAs have affected grassroots institutional and spatial systems of land tenure and resource management 
(Benjaminsen et al. 2013; Brockington, Duffy, and Igoe 2008; Goldman 2003; Hoole and Berkes 2010). However, the Saadani case is not just another example of how state-led conservation is serving as a tool for the total disruption of community livelihoods (Brockington 1999; Clements et al. 2014), or how under 'fortress' conservation schemes community land rights continue to be dismissed in the name of serving the public's interest derived from biodiversity conservation. The greatest contribution the present findings make is in describing the actual ways in which state-led conservation takes place-despite international commitments - and how it is often neither aimed at meaningful community participation, nor always motivated by the noble purpose of protecting biodiversity.

The findings add to growing concerns about ways in which the rationale for, and approaches to, strict forms of state-based conservation disregard the world's diversity of cultures and custodianship, and how they mirror the kinds of human actions that are causing biodiversity loss all around the world (Agrawal and Redford 2009; Chapin 2004; Colchester 1994; Dowie 2011; Neumann 1998). They point to an imperative to fully shift conservation debates and discourses away from stark separation of people and nature. They compel critical examination of global conservation agendas, which are centered on defining conservation progress mainly in terms of representation and extent of PAs, primarily informed by ecological data, and focused on management efforts (the "what to do") rather than on governance approaches (the question of who decides and how they decide).

Fair and effective governance is key to achieving social goals related to livelihoods and equity, and environmental conservation goals. In this regard, this case highlights two central concerns. These are the need to elaborate on and reformulate what is meant by "participatory conservation" within the current conservation framework, and a need to recast the role of the state more as a conveyer and a bridge between local efforts and international resources for conservation rather than as the main planner and implementer (and most authoritative decision-maker) in conservation deliberations and schemes.

\section{Conclusions}

The article has presented an examination of the ways in which the state-led approach to conservation, decision-making and governance, and spatial reorganization in the Saadani landscape have been detrimental to the welfare of communities concerned with conservation, and to efforts to foster environmental stewardship. Although community rights and participation in conservation have been acknowledged and incorporated into current environmental discourses in Tanzania and globally, this study adds to the body of cases demonstrating that such rights are often not comprehended and applied at the level of practice.

The goals of government authorities relating to spatial control, their prominent conceptualization of territory, the forms of interplay through which their goals have been imposed, and the conservation institutions to which they have given rise, are the pillars of state-based environmental governance. In this regard, spatial reorganization is a central instrument through which conservation approaches can affect the equitability and the effectiveness of conservation. Spatial reorganization alters the interplay among community institutions and between community institutions and state institutions. It affects jurisdiction and the degree of authority held by different actors, communal land tenure institutions, and the exercising of agency by grassroots actors, which in turn has implications for enabling the social and ecological sustainability of protected landscapes. In Saadani, state-led environmental governance and spatial reorganization not only make the national park model unbearable for communities that care about conserving biodiversity, but their results call into question the role assigned to national governments as the central actors to deliberate and implement conservation agendas.

Accumulating scholarship in the natural and social sciences points to the need for more holistic approaches to protecting biodiversity (e.g., Mora and Sale 2011; O'Riordan and Stoll-Kleemann 2002) and it demonstrates that "our ability to know the scale of what we are doing, and what fundamentally needs to be done to move us towards a sustainable outcome, has never been so well analyzed" (O'Riordan 2002: 4). Current international conservation agreements such as the Convention on Biological Diversity are, in practice, primarily focused on the extent and coverage of PAs. While they have some provisions for addressing participatory planning and acknowledging indigenous knowledge (Convention on Biological Diversity 2010), 
they lack effective measures to ensure participation and the protection of communal and indigenous land rights. The current drivers of biodiversity loss-organized poaching, unsustainable resource exploitation, ecosystem degradation, etc.- - surpass the capacity of any single community or state. It is time for conservation approaches that pitch states against communities to be replaced with a paradigm that frames conservation progress in terms of communal custodianship, shared jurisdiction and multi-level governance.

\section{References}

Agrawal, A. and K.H. Redford. 2009. Conservation and displacement: an overview. Conservation and Society 7(1): 1.

Alcorn, J.B. 1993. Indigenous peoples and conservation. Conservation Biology 7(2): 424-426.

Aubertin, C. and E. Rodary (eds.). 2011. Protected areas, sustainable land? Farnham: Ashgate.

Bagamoyo District Board 2001. Minutes of the District Board Meeting of the Committee on Proper Land Utilization on 9/11/2001 at Bagamoyo District Commissioner's Office.

Bagamoyo District Board 2002. Minutes of the District Board Meeting on 31/1/2002 at Mantep Hall, Bagamoyo District. Bagamoyo, Pwani. Tanzania: BDB.

Bagamoyo District Commissioner 2005. Dispute between TANAPA and residents of Miono Division, Mkange location, Saadani, Matipwili-Java, and Mkange villages.

Baldus, R.D., K. Roettcher and D. Broska. 2001. Saadani: an introduction to Tanzania's Future 13th National Park. In R.D. Baldus and L. Siege (eds.). Tanzania Wildlife Discussion Paper 30. GTZ and Wildlife Division Tanzania.

Barrett, C.B., K. Brandon, C.C. Gibson and H.E. Gjertsen. 2001. Conserving tropical biodiversity amid weak institutions. Bioscience 51(6): 497-502.

Benjaminsen, T.A. and I. Bryceson. 2012. Conservation, green/blue grabbing and accumulation by dispossession in Tanzania. Journal of Peasant Studies 39(2): 335-355.

Benjaminsen, T.A., M.J. Goldman, M.Y. Minwary and F.P. Maganga. 2013. Wildlife management in Tanzania: state control, rent seeking and community resistance. Development and Change 44(5): 1087-1109.

Berkes, F., Folke, C. and Colding, J. 1998. Linking social and ecological systems: management practices and social mechanisms for building resilience. Cambridge: Cambridge University Press.

Borrini-Feyerabend, G., A. Kothari and G. Oviedo, 2004. Indigenous and local communities and protected areas : towards equity and enhanced conservation: guidance on policy and practice for co-managed protected areas and community conserved areas. Best practice protected area guidelines series 11. Gland, Switzerland ; Cambridge: IUCN--the World Conservation Union.

Borrini-Feyerabend, G., M. Pimbert, M.T. Farvar, A. Kothari and Y. Renard. 2004. Sharing power: learning by doing in co-management of natural resources throughout the world. London: IIED.

Brandon, K., K.H. Redford and S.E. Sanderson (eds.). 1998. Parks in peril: people, politics and protected areas. Washington, D.C.: Island Press.

Brechin, S., G.D. Murray and C.E. Benjamin. 2007. Contested ground in nature protection: current challenges and opportunities in community-based natural resources and protected areas management. In Pretty, J., T. Benton, J. Guivant, D. Lee, D. Orr, M.J. Pfeffer and H. Ward. (eds.) Sage handbook on environment and society. Thousand Oaks: Sage. Pp. 553-577.

Brechin, S., P.R. Wilshusen, C. Fortwangler and P. West (eds.). 2003. Contested nature: promoting international biodiversity with social justice in the twenty-first century. Albany: State University Press of New York.

Brockington, D. 1999. Conservation, displacement, and livelihoods: the consequences of eviction for pastoralists moved from the Mkomazi Game Reserve, Tanzania. Nomadic Peoples 3(2): 74-96.

Brockington, D. 2002. Fortress conservation: the preservation of the Mkomazi Game Reserve, Tanzania. Oxford: James Currey. 
Brockington, D., R. Duffy, and J. Igoe. 2008. Nature unbound: conservation, capitalism and the future of protected areas. London: Earthscan.

Brockington, D. and Igoe, J. 2006. Eviction for conservation : a global overview. Conservation and Society 4(3): 424-470.

Brockington, D., Igoe, J. and K. Schmidt-Soltau. 2006. Conservation, human rights, and poverty reduction. Conservation Biology 20(1): 250-252.

Chape, S., M. Spalding, and M. Jenkins (eds.). 2008. The world's protected areas: status, values and prospects in the 21st century. Berkeley: University of California Press.

Chapin, M. 2004. A challenge to conservationists. World Watch Magazine (November/December): 17-31.

Clements, T., S. Suon, D.S. Wilkie and E.J. Milner-Gulland. 2014. Impacts of Protected Areas on local livelihoods in Cambodia. World Development 64: S125-S134.

Colchester, M. 1994. Salvaging nature: Indigenous peoples, protected areas and biodiversity conservation. Discussion Paper 55. Geneva: UNSRID.

Commission on Human Rights and Good Governance 2017. Commission on Human Rights and Good Governance: Inclusion of Uvinje Hamlet as Part of Saadani National Park. Dar Es Salaam, Tanzania.

Convention on Biological Diversity 2010. The Strategic Plan for Biodiversity 2011-2020 and the Aichi Biodiversity Targets. Document UNEP/CBD/COP/DEC/X/2. Nagoya, Japan: Secretariat of the Convention on Biological Diversity.

Craigie, I.D., J.E.M. Baillie, A. Balmford, C. Carbone, B. Collen, R.E. Green and J.M. Hutton. 2010. Large mammal population declines in Africa's protected areas. Biological Conservation 143(9): 2221-2228.

Department of Wildlife and The Republic of Tanzania 1968. 1968-1976 Saadani Game Reserve monthly reports. Dar Es Salaam, Tanzania.

Dowie, M. 2011. Conservation refugees: the hundred-year conflict between global conservation and native peoples. MIT Press.

Goldman, M.J. 2003. Partitioned nature, privileged knowledge: community-based conservation in Tanzania. Development and Change 34(5): 833-862.

Goldstein, G. 2004. Legal system and wildlife conservation: history and the law's effect on indigenous people and community conservation in Tanzania. Georgetown International Environmental Law Review 17: 481-

Hoole, A. and F. Berkes. 2010. Breaking down fences: recoupling social-ecological systems for biodiversity conservation in Namibia. Geoforum 41(2): 304-317.

Igoe, J. and Brockington, D. 2007. Neoliberal conservation: a brief introduction. Conservation and Society 5(4): 432-449.

IUCN 2009. World Commission on Protected Areas program. Gland, Switwerland: IUCN

IUCN and UNEP 2013. The World Database on Protected Areas. The World Database on Protected Areas (WDPA). doi: www.protectedplanet.net.

James, A.N., K.J. Gaston and A. Balmford. 1999. Balancing the earth's accounts. Nature 401(6751): 323-324.

Juffe-Bignoli, D., N.D. Burgess, H. Bingham, E.M.S. Belle, M.G. Lima, M. Deguignet, B. Bertzky, A.N. Milam, J. Martinez-Lopez, E. Lewis, A. Eassom, S. Wicander, J. Geldmann, A. Van Soesbergen, A.P. Arnell, B. O'Connor, S. Park, Y.N. Shi, F.S. Danks, B. MacSharry and N. Kingston. 2014. Protected planet report 2014: tracking progress towards global targets for protected areas. Cambridge: UNEPWCMC.

Legal and Human Rights Centre 2017. Uvinje eviction saga: Legal and Human Rights Centre fact-finding mission report on Saadani National Park. Dar Es Salaam, Tanzania: LHRC.

Matipwili Village 2011. Matipwili Village Council Meeting, July 26.

Mawio NewsPaper 2013. Uvinje: the government is seeking to incriminate us. November. 
Mora, C. and P.F. Sale. 2011. Ongoing global biodiversity loss and the need to move beyond protected areas: a review of the technical and practical shortcomings of protected areas on land and sea. Marine Ecology Progress Series 434: 251-266.

Mwinyamane, A.S. 1994. History of Saadani Village and Saadani Game Reserve.

Mwinyamane, A.S. 2003. Tanapa organization causes death and anxiety in Uvinje. Dar Es Salaam, Tanzania.

Neumann, R.P. 1998. Imposing wilderness: struggles over livelihood and nature preservation in Africa. Berkeley: University of California Press.

Ngorisa, V., N. Tenende and E. Msuya. 2014. A fact finding mission report on the land dispute between Saadani National Park and Uvinje Villagers. Dar Es Salaam, Tanzania.

O'Riordan, T. 2002. Protecting beyond the protected. In O'Riordan, T. and S. Stoll-Kleemann (eds.) Biodiversity, sustainability and human communities: protecting beyond the protected. Cambridge: Cambridge University Press. Pp. 1-30.

O'Riordan, T. and S. Stoll-Kleemann (eds.). 2002. Biodiversity, sustainability and human communities: protecting beyond the protected. Cambridge: Cambridge University Press.

Packer, C., H. Brink, B.M. Kissui, H. Maliti, H. Kushnir and T. Caro. 2011. Effects of trophy hunting on lion and leopard populations in Tanzania. Conservation Biology 25(1): 142-153.

Peterson, N.D. and C. Isenhour. 2014. Introduction: moving beyond the 'rational actor' in environmental governance and conservation. Conservation and Society 12(3): 229-.

Rantala, S. and H. Vihemäki. 2011. Human impacts of displacement from protected areas: lessons from the establishment of the Derema Corridor, north-eastern Tanzania. Paper presented in the 13th Biannual Conference of the International Association for the Study of the Commons, Hyderabad, India, 11--14th January. https://dlc.dlib.indiana.edu/dlc/handle/10535/7104.

Robinson, L.W. and E. Makupa. 2015. Using analysis of governance to unpack community-based conservation: a case study from Tanzania. Environmental Management 56(5): 1214-1227.

Roth, R.J. 2008. "Fixing" the forest: the spatiality of conservation conflict in Thailand. Annals of the Association of American Geographers 98(2): 373-391.

Saadani National Park. 2013. Saadani National Park: 2012-2013. Resource Protection Annual Report.

Secretariat of the Convention on Biological Diversity 2010. Global Biodiversity Outlook 3.

Stevens, S. (ed.). 1997. Conservation through cultural survival: Indigenous peoples and protected areas. Washington D.C.: Island Press.

Tanzania National Parks Authority 2002. Proposal to establish a national park, report to Bagamoyo District Council. January 31.

Tanzania National Parks Authority 2003. Saadani National Park: management zone plan environmental impact assessement. Arusha, Tanzania.

Tanzania National Parks Authority 2005. Community Conservation Services: strategic action plan (20052015). Arusha, Tanzania: TANAPA.

Tanzania National Parks Authority 2009. Saadani National Park: General Management Plan 2010-2020. Arusha, Tanzania: TANAPA.

Tanzania National Parks Authority 2011. Tanzania National Parks Authority: invitation for investors. Arusha, Tanzania: TANAPA. Archive copy

Tanzania National Parks Authority 2014a. Saadani National Park: official communication. Dar Es Salaam, Tanzania: TANAPA.

Tanzania National Parks Authority 2014b. Saadani National Park: official communication. Dar es Salaam, Tanzania: TANAPA.

The Independent Daily Newspaper 2003. News: villagers swear to die to protect the village. Dar Es Salaam, Tanzania. 
The Republic of Tanzania and Ministry of Rights and Human Settlements Development 2009. Letter of offer of right of occupancy. Bagamoyo, Pwani. Tanzania.

Treydte, A.C. 2004. Ecosystem studies on the former Mkwaja Ranch and the new Saadani National Park between 2001 and 2004. Tanzania Wildlife Discussion Paper 42. GTZ and Tanzania Wildlife.

Underdal, A. 2008. Determining the causal significance of institutions: accomplishments and challenges. In Young, O.R., L.A. King and H. Schroeder (eds). Institutions and environmental change: principal findings, applications, and research frontiers. Cambridge, Massachusetts: MIT Press. Pp. 49-78.

University of Dar Es Salaam and Institute of Resource Assessment. 1997. Environmental evaluation for tourism development in the Saadani Game Reserve. Dar Es Salaam, Tanzania.

Uvinje Subvillage 2002. Letter to the Comission on Human Rights and Good Governance: is this oppression part of human rights and good governance in the country? Bagamoyo, Pwani. Tanzania.

Uvinje Subvillage 2003. Letter to the Bagamoyo District Commissioner: report to vacate the sub-village and pave the way for animals or be forcefully evicted. Bagamoyo, Pwani. Tanzania.

Venter, O., R.A. Fuller, D.B. Segan, J. Carwardine, T.M. Brooks, S.M.H. Butchart, M. Di Marco, T. Iwamura, L. Joseph, D. O'Grady, H.P. Possingham, C. Rondinini, R.J. Smith, M. Venter and J.E.M. Watson. 2014. Targeting global protected area expansion for imperiled biodiversity. PLoS Biology 12(6).

Waldron, A., A.O. Mooers, D.C. Miller, N. Nibbelink, D. Redding and T.S. Kuhn. 2013. Targeting global conservation funding to limit immediate biodiversity declines. Proceedings of the National Academy of Sciences 1-5.

Watson, J.E.M., N. Dudley, D.B. Segan and M. Hockings. 2014. The performance and potential of protected areas. Nature 515(7525): 67-73.

West, P. and S. Brechin (eds.). 1991. Resident peoples and national parks: social dilemmas and strategies in international conservation. Tucson: University of Arizona Press.

West, P., J. Igoe and D. Brockington. 2006. Parks and peoples: the social impact of protected areas. Annual Review of Anthropology 35(1): 251-277.

Wilson, J.A. 2002. Scientific uncertainty, complex systems, and the design of common-pool institutions. In Ostrom, E., T. Dietz, T., N. Dolšak, P.C. Stern, S. Stonich and E.U. Weber (eds). The Drama of the commons. Washington, D.C.: National Academy Press. Pp. 327-360.

World Resources Institute, United Nations Development Program, United Nations Environment Program and The World Bank 2003. World Resources 2002-2004: decisions for the Earth: balance, voice, and power. Washington D.C.: World Resources Institute.

Young, O.R. 1999. Governance in world affairs. Ithaca: Cornell University Press.

Zimmerer, K.S. and K.R. Young (eds.). 1998. Nature's geography: new lessons for conservation in developing Countries. Madison: University of Wisconsin Press.

Zimmerman, M.A. 1995. Psychological empowerment: issues and illustrations. American Journal of Community Psychology. 23(5): 581-599. 